\title{
COM O GRÊMIO ONDE O GRÊMIO ESTIVER: AS CAPAS DO JORNAL ZERO HORA/RS NA CONQUISTA DA LIBERTADORES DA AMÉRICA 2017
}

\author{
WITH THE GRÊMIO WHERE THE GRÊMIO IS: THE COVERS OF ZERO \\ HORA/RS IN THE CONQUEST OF COPA LIBERTADORES DA AMÉRICA 2017
}

\author{
Gustavo Roese Sanfelice \\ Universidade Feevale - RS \\ sanfeliceg@feevale.br \\ Maurício Barth \\ Universidade Feevale - RS \\ mauricio@feevale.br \\ Debora Wissman \\ Universidade Feevale - RS \\ deborawissmann@feevale.br \\ Arthur Matheus Schneider \\ Universidade Feevale - RS \\ arthur_m_schneider@hotmail.com
}

RESUMO. O presente trabalho tem como objetivo analisar como, do ponto de vista imagético, apresentaram-se as capas dos jornais Zero Hora/RS nos dias posteriores às partidas do Grêmio Foot-Ball Porto Alegrense nas fases semifinal e final da Copa Libertadores da América 2017. Analisamos os códigos cromáticos, tipográficos, fotográficos e morfológicos presentes em quatro capas do jornal, utilizando como base os conceitos de análise da imagem de Georges Péninou (1973). Ao fim do estudo, foi possível identificar a maneira como o veículo transmitiu suas mensagens, bem como se organizaram as informações imagéticas presentes em sua página inicial.

Palavras-chave: Imagem. Jornal. Capa.

ABSTRACT. This paper aims to analyze how, from an imagery point of view, the covers of the newspapers Zero Hora/RS were presented in the days following the matches of the Grêmio Foot-Ball Porto Alegrense in the final phase of the Copa Libertadores da America 2017. We analyze the chromatic, typographic, photographic and morphological codes presents in two covers of the newspaper, using as basis the concepts of image analysis of Georges Péninou (1973). At the end of the study, it was possible to identify the way that the vehicle transmitted its messages, as well as to organize the imaging information present on its home page.

Keywords: Image. Newspaper. Cover.

\section{Introdução}

O jornal é um dos meios de comunicação que mais atrai a atenção do público (SHOR, 2019; TEKELI-YESIL; KAYA; TANNER, 2019). Nesse sentido, um dos grandes atrativos de um jornal são suas matérias futebolísticas que, constantemente, viram assunto principal nas capas dos impressos. Isso porque o futebol é um esporte conhecido no mundo inteiro e costuma mover multidões e, no Brasil, não é diferente. $\mathrm{O}$ 
país respira o esporte e essa paixão pode ser constatada pelas cifras que são feitas com a compra/venda de produtos licenciados e, principalmente, os valores multimilionários investidos na Publicidade dos grandes clubes de futebol ${ }^{1}$.

Dessa forma, destaca-se no meio futebolístico a Copa Libertadores da América, uma competição de futebol organizada pela CONMEBOL (Confederação SulAmericana de Futebol) que reúne os melhores clubes da América do Sul. A competição é uma das mais prestigiadas do mundo e o vencedor garante uma vaga no Mundial de Clubes da FIFA. Os confrontos se iniciam com uma fase de grupos e, por fim, os melhores se enfrentam em uma disputa de mata-mata ${ }^{2}$ para decidir o grande campeão que, em 2017, foi o Grêmio Foot-Ball Porto Alegrense.

Destarte, o presente trabalho questiona: como, do ponto de vista imagético, apresentaram-se as capas do Jornal Zero Hora/RS no dia posterior aos jogos do Grêmio nas fases semifinal e final da Copa Libertadores da América 2017? Estabelece-se, portanto, para este trabalho, a seguinte hipótese: as capas tiveram um tom mais azulado por conta das cores do Grêmio, as imagens retrataram sempre o sentimento do torcedor, seja ele de felicidade ou de angústia e dependiam do resultado obtido. A personagem presente na capa foi o que mais se destacou na partida, seja positiva ou negativamente. Para responder o problema proposto, analisam-se quatro capas do referido jornal, aplicando-se a Análise da Imagem de Péninou (1973), a qual é demonstrada na seção seguinte.

\section{Metodologia}

Esta pesquisa, do ponto de vista de seus objetivos, pode ser classificada como Descritiva, do ponto de vista de seus procedimentos técnicos como Bibliográfica e do ponto de vista da abordagem do problema como Qualitativa. Para sua etapa de análise de dados utilizou-se a Análise de Imagem proposta por Georges Péninou (1973). O autor relata que as mensagens imagéticas podem ser emitidas por meio de códigos. Tais elementos fazem parte de uma informação significada, onde há a obrigação de comunicar e, por consequência, se fazer notar. O quadro a seguir expressa os códigos

\footnotetext{
1 Fla fecha patrocínio que renderá $\mathrm{R} \$ 190$ milhões ao clube em 6 anos. Disponível em: <http://globoesporte.globo.com/futebol/times/flamengo/noticia/2016/12/fla-fecha-patrocinio-que-renderacerca-de-r-200-milhoes-ao-clube-em-6-anos.html>. Acesso em: 03 jan. 2019.

${ }^{2}$ Disputa eliminatória entre dois adversários que se enfrentam para decidir qual dos dois passa à próxima fase de uma competição.
} 
elencados por Péninou (1973), subdivididos em cromático, tipográfico, fotográfico e morfológico.

Quadro 1 - Códigos

\begin{tabular}{|c|c|c|}
\hline Códigos & & Observações \\
\hline Cromático & \multicolumn{2}{|c|}{ Refere-se à psicodinâmica das cores como impacto visual. } \\
\hline Tipográfico & \multicolumn{2}{|c|}{$\begin{array}{c}\text { Diz respeito à tipografia como elemento marcante, seja através de isolamento } \\
\text { espacial, modificação da dimensão dos caracteres ou aposição de traços } \\
\text { distintivos. }\end{array}$} \\
\hline Fotográfico & \multicolumn{2}{|c|}{$\begin{array}{l}\text { Alude-se às técnicas seletivas de planos (destaque do produto, engomagem do } \\
\text { fundo) e às técnicas enfáticas de planos (manipulação da escala dimensional } \\
\text { ou volumétrica, efeitos cênicos). }\end{array}$} \\
\hline \multirow[t]{3}{*}{ Morfológico } & \multirow{3}{*}{$\begin{array}{l}\text { Explicita a geografia da } \\
\text { imagem publicitária onde, } \\
\text { em um anúncio, o olhar } \\
\text { seleciona as superfícies } \\
\text { portadores das informações- } \\
\text { chave. }\end{array}$} & $\begin{array}{l}\text { Construção focalizada: as linhas de força } \\
\text { convergentes conduzem, necessariamente, a } \\
\text { um ponto comum. }\end{array}$ \\
\hline & & $\begin{array}{c}\text { Construção axial: o produto ocupa o centro da } \\
\text { página. }\end{array}$ \\
\hline & & $\begin{array}{l}\text { Construção sequencial: há um encadeamento } \\
\text { de cenas (imagens), no qual o olhar, após ser } \\
\text { levado a uma ilustração, dirige-se a outra e } \\
\text { assim por diante, até chegar ao logotipo do } \\
\text { anunciante. }\end{array}$ \\
\hline
\end{tabular}

Fonte: Os autores, com base em Péninou (1973)

\section{Imagem}

Imagens têm sido meios de expressão da cultura humana desde as pinturas préhistóricas das cavernas, milênios antes do aparecimento do registro da palavra pela escritura (SANTAELLA; NÖTH, 1997, p.13). Joly (1996) comenta que o termo imagem é tão utilizado, com tantos tipos de significação sem vínculo aparente, que parece complicado dar uma definição simples dele, de forma que recubra todos os seus empregos. Segundo a autora, mais impressionante ainda é que, apesar da diversidade de significações da palavra, ainda assim conseguimos compreendê-la.

Deleuze (1992) conceitua a palavra imagem como a representação de um objeto ou a reprodução mental de uma sensação na ausência da causa que a produziu. Tal representação mental é formada a partir de lembranças, vivências e percepções passadas e passíveis de serem modificadas por novas experiências. O autor comenta que uma 
imagem pode servir de signo quando representa um conteúdo cujos caracteres não são visualmente refletidos por ela. Santaella e Nöth (1997) complementam que:

\footnotetext{
"não há imagens como representações visuais que não tenham surgido de imagens na mente daqueles que as produziram, do mesmo modo que não há imagens mentais que não tenham alguma origem no mundo concreto dos objetos visuais" (SANTAELLA; NÖTH, 1997, p. 15).
}

Joly (1996), ao abordar as noções de imagem, seus usos e significações, explica que imagem é um termo com diversos significados e sua construção passa por alguém que a produz ou reconhece. Imagens podem ser mentais, visuais ou virtuais. Elas podem ser materiais ou imateriais, naturais ou fabricadas. "Imagem é antes de mais nada algo que se assemelha a outra coisa" (JOLY, 1996, p. 38). Ambrose e Harris (2009) complementam que as imagens podem ter vários significados cognitivos e denotativos e geralmente são advindos de algum aspecto de determinada cultura.

Santaella e Nöth (1997) dividem o mundo das imagens em dois domínios. O primeiro deles é o das imagens como representações visuais: desenhos, pinturas, gravuras, fotografias e as imagens cinematográficas. Nesse sentido, as imagens são objetos materiais, signos que representam o nosso meio ambiente visual. O segundo é o domínio imaterial das imagens na nossa mente. Neste domínio, imagens aparecem como visões, fantasias, imaginações, esquemas modelos ou, em geral, como representações mentais. Ambos os domínios da imagem não existem separados, pois já estão ligados na sua gênese.

\subsection{Cor}

Somos bombardeados por inúmeras cores todos os dias. Elas são um fenômeno que produz diversas sensações sobre nós e são possíveis apenas por causa de um sentido específico, a visão. A cor é intangível, não se pode sentir o seu cheiro, ser ouvida e muito menos sentida. Ela não é específica de um objeto e seu significado é distinto de pessoa para pessoa.

Ambrose e Harris (2005) definem que as cores imprimem um significado e que a nossa interpretação dependerá de alguns fatores como bagagem cultural, tendências, idade e preferências individuais. Fraser e Banks (2013) definem que uma cor, ou uma composição de cores, pode significar algo completamente diferente para cada pessoa que olha para ela. Para eles, ela influencia tudo, tem o poder de modelar, acidental ou intencionalmente, nossa compreensão e pode comunicar complexas interações de 
associação e simbolismo ou uma simples mensagem de forma mais clara que as palavras, por exemplo. Ambrose e Harris (2005) complementam que a cor é a forma mais imediata de comunicação não verbal. Ela pode ter inúmeros significados intrínsecos, ligados a diversas emoções e humores. Pedrosa (2006) reforça esses sentimentos e, ao buscar um pouco da origem da cor, diz que, em uma história de mais de três milhões de anos, o homem descobriu e manipulou a cor e a levou a um processo evolutivo muito grande. Para ele, a cor tornou-se o mais extraordinário meio de projeção de sentimentos, conhecimentos, magia e encantamento.

Ambrose e Harris (2005) estabelecem, ainda, três valores que são utilizados para descrever as cores mais detalhadamente. São eles: matiz, saturação e brilho. Matiz, ou cor, é a característica que nos ajuda a diferenciar, visualmente, uma cor da outra e é formada pelos diferentes comprimentos de onda da luz. A saturação, ou croma, refere-se à pureza da cor e seus níveis descrevem a tendência de ir em direção ou a se afastar do cinza. Já o brilho se refere ao quanto a cor é clara ou escura e suas mudanças podem ser feitas a partir da mistura da cor com diferentes proporções de branco e preto.

\subsection{Tipografia}

A tipografia compreende o desenho e a produção de letras e a sua adequada distribuição e espacejamento sobre uma superfície para transmitir informação e facilitar a compreensão (NIEMEYER, 2010, p.14). Silva (1985) entende que a tipografia tem como objetivo básico comunicar uma informação por meio da letra impressa. Niemeyer (2010) aponta que uma das funções da tipografia é de estimular a sua percepção da estrutura implícita ao texto, facilitar a compreensão da informação, conduzir o leitor à leitura e aprofundar o seu entendimento.

Fonseca (2008) estabelece que, para ele, a tipografia é considerada uma das maiores revoluções ocorridas no mundo, pois ela democratizou a distribuição da informação e provocou mudanças sociais, políticas, religiosas e econômicas radicais em todos os povos do mundo.

Para Fonseca (2008), a maneira como os tipos são selecionados, montados e organizados para formar as palavras, sentenças, parágrafos e páginas, é um processo que, por mais de quinhentos anos, não foi modificado. Criada na Renascença Europeia, ela naturalmente foi aprimorada, tanto no desenvolvimento da tecnologia como na 
metodologia de procedimentos, porém, em sua essência, a composição de textos continua a mesma.

Segundo Strunck (2012), podemos dividir os alfabetos em cinco grandes grupos utilizando as serifas, que são as terminações dos caracteres, para classificá-los.

Figura 1 - Exemplos de Alfabetos Tipográficos

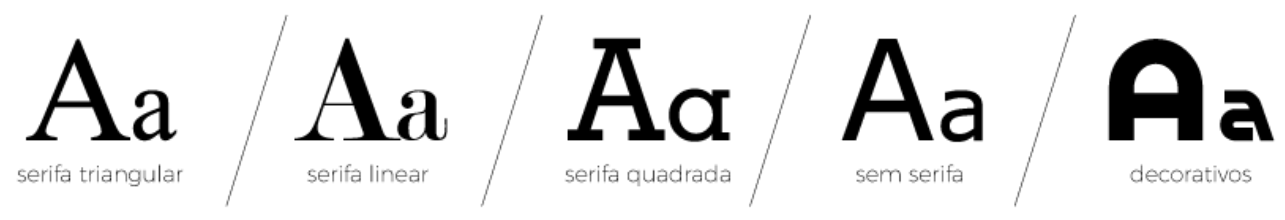

Fonte: Elaborado pelos autores

Strunck (2012) também define que algumas fontes apresentam variações no seu desenho, porém, essas variações não causam uma perda de qualidade em suas características. Para ele, essas são as fontes mais adequadas, pois tem a capacidade de se apresentar hierarquicamente e ordenar as informações com mais qualidade e fluidez. $\mathrm{Na}$ figura 2, apresentamos um exemplo de fonte que possui essas características.

Figura 2 - Fonte Tipográfica Helvetica com algumas de suas variações

\section{Helvetica light \\ Helvetica condensed \\ Helvetica medium \\ Helvetica black}

Fonte: Elaborado pelos autores

\subsection{Fotografia e composição}

Segundo Hedgecoe (2005), a palavra "fotografia" significa desenhar com luz. Para ele,

"a fotografia é tanto uma ciência quanto uma arte, e um entendimento das técnicas básicas contribui para que se produzam composições criativas de boa qualidade.” (HEDGECOE, 2005, p.37). 
Para Langford (2003), a fotografia consiste em um conjunto de ciência prática, imaginação, habilidade técnica e capacidade de organização. Cesar (2013) complementa afirmando que uma boa fotografia é composta pelo equilíbrio, o tema, a composição e, acima de tudo, a luz.

Präkel (2013) define composição como "um processo de identificação $e$ organização de elementos visuais para produzir uma imagem coerente. Tudo o que está em uma imagem forma a sua 'composição"” (PRÄKEL, 2013, p.11). Para Dondis (1997), a composição da imagem tem a capacidade de reproduzir um enorme poder de persuasão sobre o receptor. "Para compreender os princípios da composição, precisamos separar, formalmente, as partes constituintes de uma imagem em linha, formato, tom e forma, textura, espaço e cor" (PRÄKEL, 2013, p.11).

\section{Análises: o caminho do tri campeonato}

\subsection{Semifinal - Jogo de ida: Barcelona X Grêmio}

Figura 3 - Capa ZH 26 de outubro de 2017

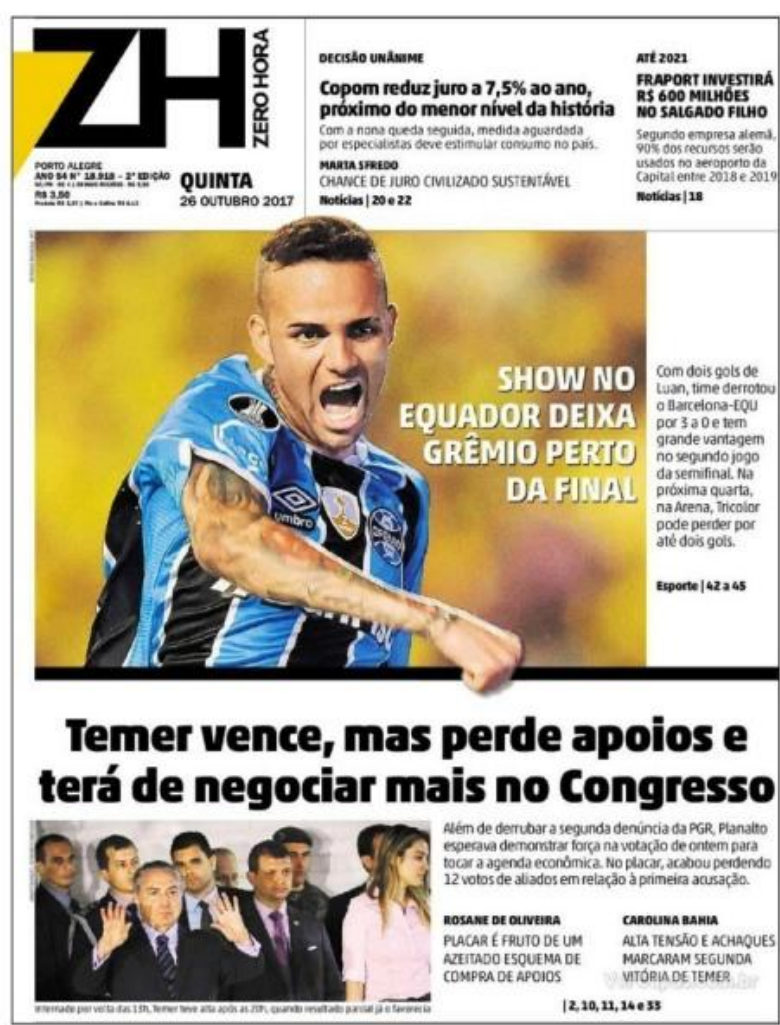

Fonte: https://www.vercapas.com.br/edicao/capa/zero-hora/2017-10-26.html 
A análise nos permite perceber algumas cores preponderantes na capa. São elas: o azul, identificada com ênfase na camisa do jogador do Grêmio; o preto, presente na tipografia, no logotipo do veículo (Zero Hora) e, também, no uniforme do jogador do Grêmio; e o amarelo, também exibido no logotipo do Jornal Zero Hora, mas, principalmente, ao fundo da imagem que estampa o jogador do Grêmio no momento da comemoração de um dos 3 gols marcados pela equipe na partida contra o Barcelona do Equador.

O código tipográfico foi analisado com base em três elementos: (1) tamanho, não possuindo um tamanho padrão, nem nas chamadas e nem nos textos de apoio; (2) cor, predominantemente apresentado na cor preta, alterando-se apenas na chamada da matéria relacionada ao jogo do Grêmio, onde o branco ganha o protagonismo; (3) o alinhamento que, em grande parte da página, é feito para a esquerda, a caminho do restante das páginas do periódico. Esse padrão é desfeito apenas na chamada principal do jogo onde o alinhamento é feito à direita e na notícia relacionada ao então presidente Temer, que está disposta em um alinhamento centralizado.

A cor preta da tipografia é uma padronagem utilizada na maior parte do jornal. Ela possui grande contraste com o papel jornal que é branco, auxiliando, assim, a leitura. Os tamanhos da tipologia não seguem padrão algum. Essa dimensão é determinada com base na importância da matéria e sua disposição é feita conforme a divisão dos assuntos abordados na capa.

A fotografia em destaque traz o jogador do Grêmio, Luan, comemorando um dos seus dois gols no jogo de ida contra o Barcelona. A imagem, que está posicionada ao centro da capa, possui um enquadramento fechado e centraliza o seu foco no jogador, o elemento em destaque. Ao fundo do clique, não temos muitas informações por conta do desfoque, mas presume-se que seja a torcida do Barcelona que possui uniforme amarelo; seu desfoque pode ser relacionado ao show do time gremista que, ao vencer por $3 \times 0$, roubou todos os holofotes na noite anterior. Sobrepondo-se à imagem, alinhado em direção ao jogador, é possível identificar o título da matéria "Show no Equador deixa Grêmio perto da final", deixando claro que o craque gremista foi o destaque da partida. A figura possui, ainda, um efeito de sobreposição acima das linhas que o jornal utiliza para dividir os assuntos da capa. Esse efeito resulta em um impacto visual maior no receptor que, por sua vez, tende a observar com mais atenção a imagem. 
Posicionado no canto direito da página, ao lado da imagem, encontra-se o texto de apoio que explica, brevemente, como a equipe do Grêmio garantiu uma boa vantagem para o jogo da volta, na Arena do Grêmio, que ocorreria na quarta-feira mais próxima. A outra notícia em destaque na página, posicionada na parte inferior do periódico, é relacionada a política e diferente dos outros títulos, esse possui alinhamento centralizado.

\subsection{Semifinal - Jogo de volta: Grêmio X Barcelona}

Figura 4 - Capa ZH 2 de novembro de 2017

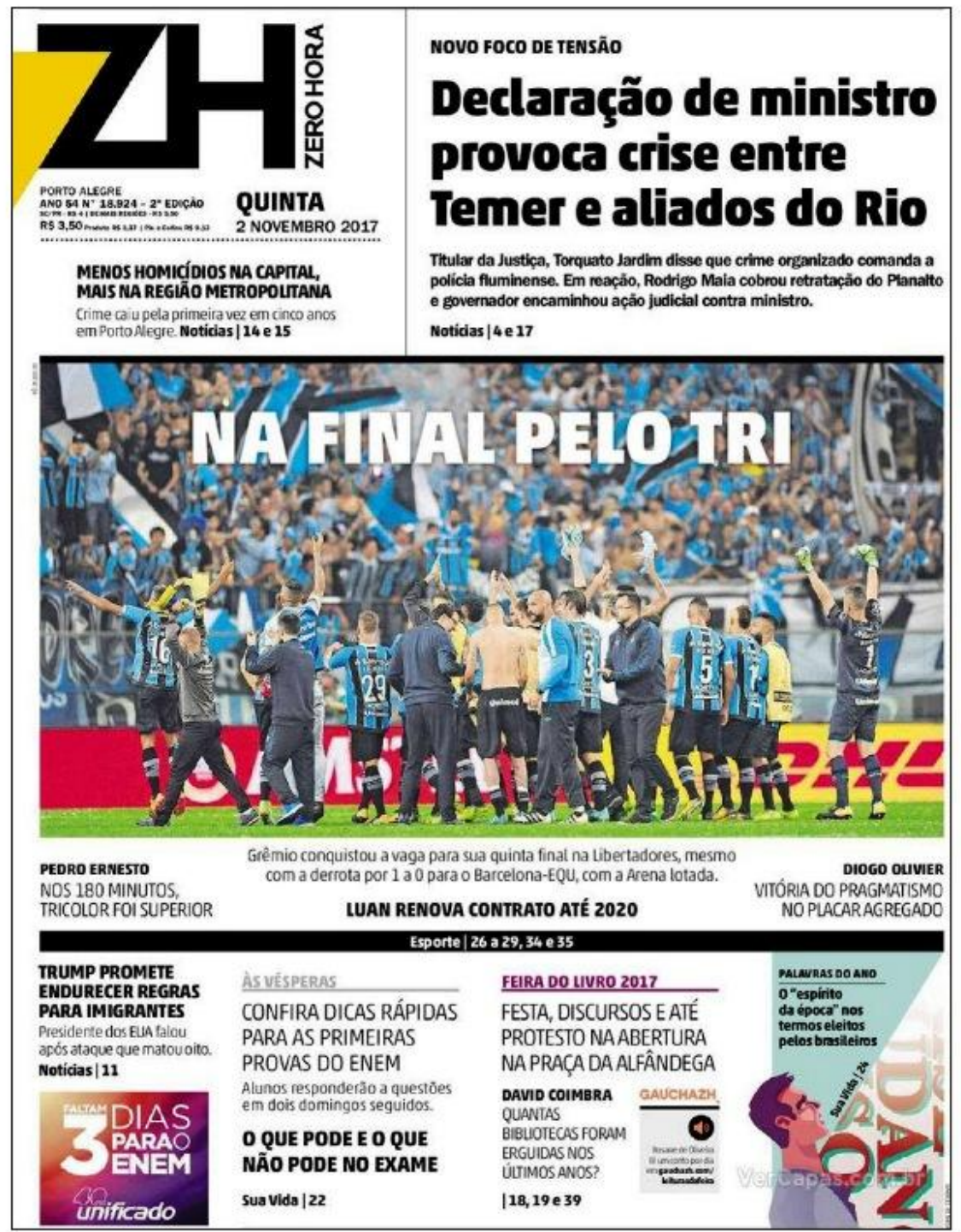

Fonte: https://www.vercapas.com.br/edicao/capa/zero-hora/2017-11-02.html 
$\mathrm{Na}$ análise da capa através de seus códigos cromáticos, podemos identificar, no mínimo, cinco cores que se destacam. São elas: o preto, presente no logo do jornal; na tipografia, que é apresentada nessa cor em sua quase totalidade e em detalhes na foto referente ao jogo do Grêmio, como bandeiras e uniformes do clube; o amarelo, em destaque também no logotipo do jornal e na placa de Publicidade da imagem do jogo do Grêmio; o vermelho, encontrado nas placas de Publicidade da foto referente ao jogo do Grêmio e em outros dois anúncios publicitários localizados na parte inferior do jornal; o azul, aparente com evidência na foto do jogo, nos uniformes dos jogadores e na torcida que, por sua vez, veste as camisas e movimenta as bandeiras do seu clube do coração; o verde, também aparente no gramado da foto que registrou o momento de comemoração da classificação da equipe gaúcha para a fase final da Copa Libertadores da América 2017; e, por último, o roxo, que aparece mais discretamente na parte inferior da capa em um anúncio do Unificado, no título da matéria referente à Feira do Livro de Porto Alegre e em um personagem ilustrado que faz parte de uma matéria chamada "Palavras do ano".

Ao observarmos o código tipográfico, destacamos a predominância da cor preta nos títulos e nos textos de apoio. Essa cor não foi escolhida ao acaso pois, além da sobriedade necessária para a leitura das notícias, contrasta- bem com o papel jornal que possui coloração branca/clara, auxiliando, assim, na leitura do conteúdo. Apesar desta predominância, o título que possui maior tamanho e destaque na capa é o referente ao jogo do Grêmio que se encontra na cor branca. Perceptível, também, é a falta de padrão que o jornal tem quando se trata do tamanho e espessura das fontes.

A fotografia principal da capa possui ângulo aberto e destaca a comemoração da equipe e da torcida do time do Grêmio, após perder por 1x0 para o Barcelona, porém, mesmo assim, conseguiu se classificar para a final da Copa Libertadores da América 2017, devido aos seus três gols marcados fora de casa. Os membros da equipe gaúcha aparecem comemorando a classificação e agradecendo o apoio da sua torcida.

Sobre a imagem temos o título "Na final pelo tri", que retrata o momento do time gremista e os acontecimentos da imagem que ilustra o feito do clube gaúcho junto a sua torcida. A imagem, como Ambrose e Harris (2009) definem, pode ter vários significados; esta em questão traz consigo uma espécie de redenção que é a conquista da vaga para a final, como também a equipe unida e em busca de um mesmo objetivo que é ser campeão. 
A imagem cobre boa parte da capa, o que evidencia mais ainda a importância da matéria para a edição do periódico. Logo abaixo da foto, podemos perceber títulos de colunas relacionadas à partida, assim como um breve resumo da classificação e uma chamada relacionada à renovação de contrato, até 2020, do atacante e craque gremista, Luan.

\subsection{Final. - Jogo de ida: Grêmio X Lanús}

Figura 5 - Capa ZH 23 de novembro de 2017

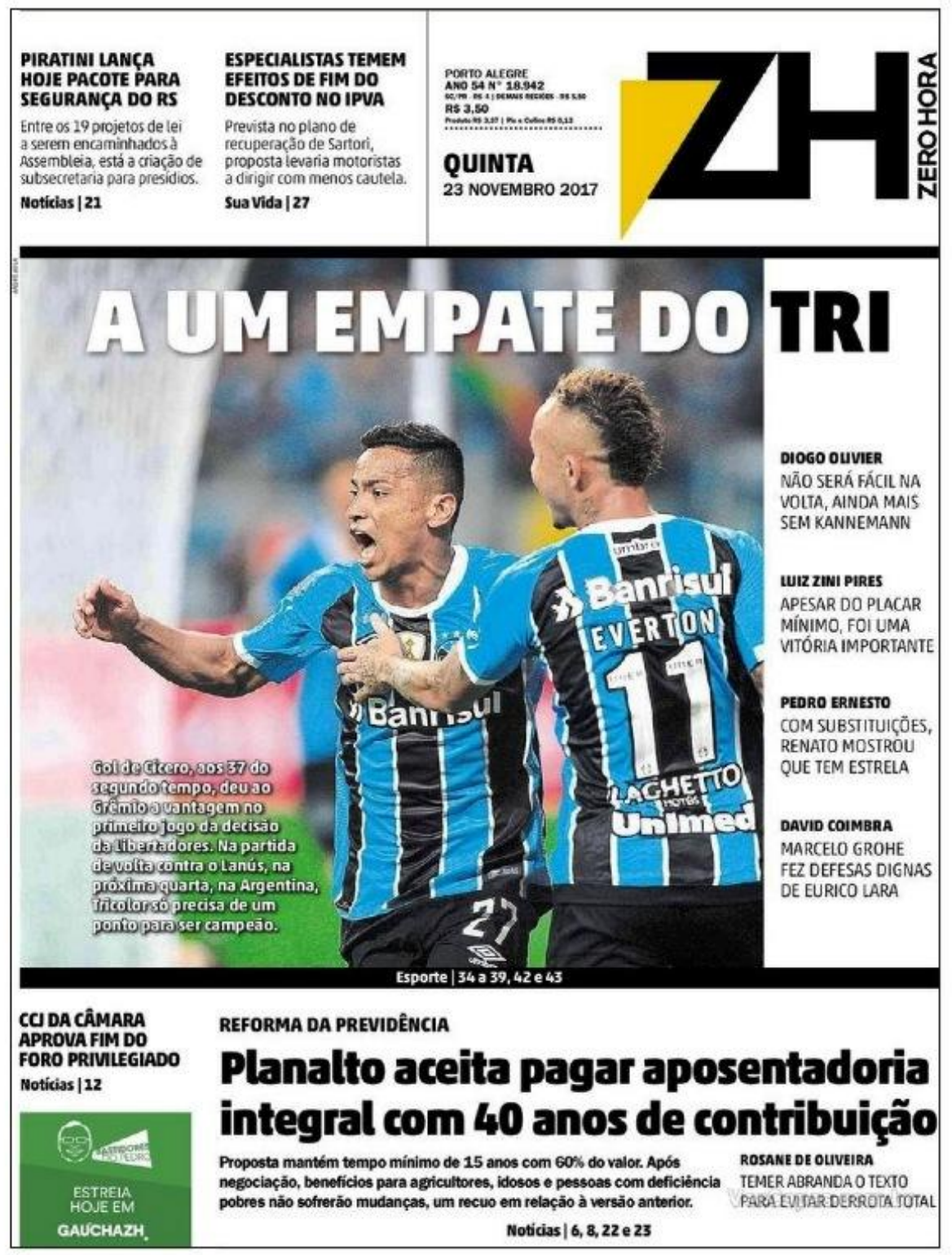

Fonte: https://www.vercapas.com.br/edicao/capa/zero-hora/2017-11-23.html 
A capa da edição do dia 23 de novembro de 2017, do Jornal Zero Hora, possui algumas cores em destaque como preto, azul, amarelo e verde. Como destacam Fraser e Banks (2013), as cores têm o poder de influenciar de forma acidental e/ou intencional a compreensão do receptor. O preto pode ser identificado em grande parte da tipografia como também no uniforme dos jogadores do time do Grêmio. Já o amarelo está presente apenas no logotipo da Zero Hora, porém, se destaca em meio à escrita escura e fundo claro. O azul está exposto nos elementos principais da imagem relacionada ao jogo do Grêmio e o verde está visível no gramado do estádio e em um anúncio relacionado a algum conteúdo exclusivo do jornal $\mathrm{ZH}$, que está presente no canto inferior esquerdo da página.

A tipografia da capa é apresentada quase que, em sua maioria, na cor preta. Essa cor quando utilizada, facilita a leitura e destaca a escrita pelo seu alto contraste com o papel jornal, que é branco. O padrão existente nas cores não está presente nos tamanhos que, tanto nas chamadas como nos textos de apoio, estão desbalanceadas, porém, equilibradas no contexto geral do layout. Suas posições e dimensões são determinadas conforme assunto e relevância das notícias. A chamada que se sobressai das demais é a relacionada ao jogo do Grêmio que possui em grande parte a coloração branca e, no restante, a cor preta.

Em destaque, ocupando cerca de meia página, temos a imagem referente ao jogo do Grêmio. Posicionada ao centro e alinhada à esquerda, a foto retrata a comemoração do autor do único gol da partida, Cícero do time do Grêmio. Junto a ele é possível identificar o atacante gremista Everton que comemora o gol que deu a vantagem ao Grêmio para o jogo de volta, em Lanús na Argentina. Sob a imagem identifica-se o título "A um empate do tri" que se utiliza de um leve efeito de sombra por detrás da área escrita em branco para auxiliar a leitura, propondo um contraste maior, destacando ainda mais a chamada.

Sob a imagem temos, também, uma legenda que explica, em poucas palavras, como foi o jogo e o seu acontecimento principal: o gol do time do Grêmio, aos trinta e sete minutos do segundo tempo da partida. Também alinhado à esquerda, porém posicionados no canto direito da capa, podemos identificar o que os colunistas de esporte do Jornal ZH se propuseram a escrever em relação a partida. A fotografia possui um tamanho notável que cobre, aproximadamente, meia página. Tal destaque pode ser justificado pelo alto nível de interesse do público pelo esporte relacionado à notícia. 
Para a divisão do conteúdo de esportes, o veículo se utilizou de bordas pretas que estão presentes nos extremos superiores e inferiores da imagem com os jogadores do time do Grêmio. Elas se destacam, pois são mais grossas que as usuais e auxiliam o receptor a compreender os limites de algum assunto específico (STRUNCK, 2012).

\subsection{Final - Jogo de volta: Lanús X Grêmio}

Figura 6 - Capa ZH 30 de novembro de 2017

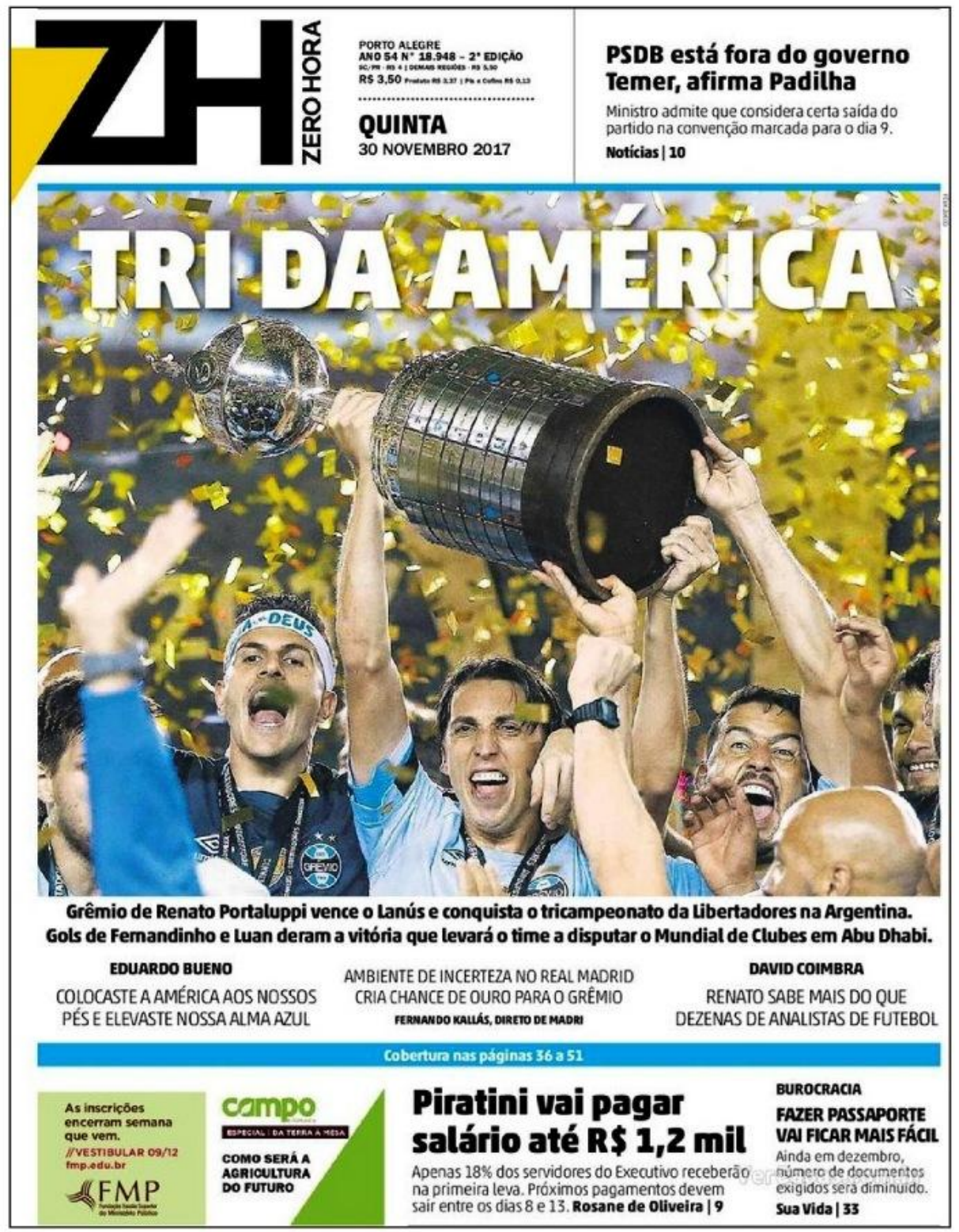

Fonte: https://www.vercapas.com.br/edicao/capa/zero-hora/2017-11-30.html

A capa do Jornal Zero Hora, um dia após a grande final da Copa Libertadores da América 2017, estampa o título "Tri da América", alusivo à partida da noite anterior em 
que a equipe do Grêmio, pelo placar de 2x1, derrotou o Lanús da Argentina. Ela traz consigo algumas cores predominantes como o preto - aparente principalmente na tipografia do periódico -, o amarelo - exposto no logo do Jornal Zero Hora e mais em evidência ainda na foto de campeão da América com os papéis picados que foram lançados sobre os jogadores da equipe do Grêmio no momento da comemoração do título -, o verde - que aparece com menos destaque no canto inferior esquerdo da capa, em dois anúncios publicitários - e o azul - cor que é visível nos uniformes dos gremistas e, também, nas faixas que dividem o conteúdo da publicação por assunto/relevância.

Presente quase que em sua totalidade na cor preta, a tipografia da capa não possui padrão em relação a tamanho, espessura e alinhamento como definiu Strunck (2012). O preto da escrita possui um bom contraste com o papel jornal, o que auxilia a leitura. Com um tamanho bastante superior aos demais textos, coloração branca e posicionado ao centro da página, identifica-se o título "Tri da América". Os demais títulos e textos de apoio detêm tamanhos menores e seguem o padrão de cor (o preto).

Ocupando cerca de meia página, a imagem que retrata o momento de comemoração da conquista do maior campeonato da América do Sul, a Copa Libertadores da América, possui ângulo fechado e foca os jogadores da equipe gaúcha e no tão sonhado troféu que havia sido conquistado pelo clube. Na imagem, é possível identificar o goleiro Marcelo Grohe, o lateral direito Edilson, o preparador de goleiros Rogério Godoy e os zagueiros Walter Kannemann, Rafael Thyere e Pedro Geromel, que está levantando o troféu que possui, em seu corpo, marcados todos os campeões anteriores da competição continental que teve início no ano de 1960. Os semblantes dos jogadores evidenciam a emoção sentida naquele momento.

Ao fundo da foto, percebe-se a chuva de papéis picados, de cor amarela, utilizada para abrilhantar ainda mais o momento de comemoração do mais novo campeão da América. Abaixo da imagem principal há uma legenda que enaltece o treinador gremista, Renato Portaluppi, e referencia os autores dos gols da equipe do Grêmio - Fernandinho e Luan. Próximo à legenda, temos as chamadas de alguns colunistas e o título "Ambiente de incerteza no Real Madrid cria chance de ouro para o Grêmio", remetendo diretamente ao confronto que as duas equipes - Grêmio e Real Madrid-, possivelmente teriam no Mundial de Clubes que reúne os vencedores dos campeonatos continentais - nesse caso, a Copa Libertadores da América (Grêmio) e a Liga dos Campeões (Real Madrid). 


\subsection{Considerações gerais sobre as capas}

O quadro a seguir demonstra, sinteticamente, apontamentos gerais sobre cada uma das capas analisadas.

\section{Quadro 2 - Síntese das capas}

\begin{tabular}{|c|c|c|}
\hline Data & Fase & Síntese \\
\hline $\begin{array}{c}26 \text { de } \\
\text { outubro } \\
\text { de } 2017\end{array}$ & $\begin{array}{l}\text { Semifinal } \\
\text { Jogo de } \\
\text { ida }\end{array}$ & $\begin{array}{l}\text { A análise dessa capa resultou na identificação de, pelo menos, três cores } \\
\text { predominantes. A cor preta é uma delas, e se faz presente em grande parte da } \\
\text { tipografia, sendo alterada para branco apenas no título relacionado ao jogo do } \\
\text { Grêmio, onde o branco assume o protagonismo. Na imagem em destaque, } \\
\text { identifica-se o jogador Luan comemorando um dos seus dois gols marcados na } \\
\text { partida contra o Barcelona do Equador que acabou no placar de } 3 \times 0 \text {. Luan foi o } \\
\text { destaque da partida e a capa do dia } 26 \text { de outubro deixou isso bem claro ao } \\
\text { mostrá-lo em evidência. O personagem da partida ainda teve outro elemento } \\
\text { que o destacou: um efeito de sobreposição que recortou e transpassou uma parte } \\
\text { de sua cabeça na parte de cima da imagem e a sua mão na parte de baixo da } \\
\text { mesma. Esse efeito auxilia a realçar, ainda mais, a fotografia/matéria. }\end{array}$ \\
\hline $\begin{array}{c}02 \mathrm{de} \\
\text { novembro } \\
\text { de } 2017\end{array}$ & $\begin{array}{c}\text { Semifinal } \\
\text { Jogo de } \\
\text { volta }\end{array}$ & $\begin{array}{l}\text { Apresentada com pelo menos cinco cores dominantes, essa capa teve como } \\
\text { principal destaque a fotografia do grupo da equipe gremista comemorando a } \\
\text { classificação para a final da Copa Libertadores da América } 2017 \text { junto à sua } \\
\text { torcida no final do jogo. Com o resultado negativo de 0x } 1 \text {, porém } 3 \times 1 \text { no placar } \\
\text { agregado, o clube gaúcho chegava novamente à final da principal competição } \\
\text { sul americana de futebol. A foto do grupo em conjunto comemorando remete à } \\
\text { união de forças que culminou na classificação e no agradecimento à torcida } \\
\text { pelo apoio dado até então. Em destaque temos, também, o título escrito na cor } \\
\text { branca, "Na final pelo tri", e com um tamanho avantajado em relação a outras } \\
\text { chamadas da edição. Novamente, observou-se a predominância da coloração } \\
\text { preta na tipografia. }\end{array}$ \\
\hline $\begin{array}{c}23 \mathrm{de} \\
\text { novembro } \\
\text { de } 2017\end{array}$ & $\begin{array}{l}\text { Final } \\
\text { Jogo de } \\
\text { ida }\end{array}$ & $\begin{array}{l}\text { Com pelo menos quatro cores predominantes a capa possui tipografia } \\
\text { padronizada na coloração preta, se alterando apenas no título remetente ao jogo } \\
\text { do Grêmio x Lanús pela final da Copa Libertadores da América } 2017 \text {. No título } \\
\text { a tipografia é composta por, além do preto, a cor branca e possui um tamanho } \\
\text { considerável em relação às outras informações do periódico. O título "A um } \\
\text { empate do tri" está sobreposto, em quase sua totalidade, na imagem que retrata } \\
\text { o exato momento em que Cícero, autor do único gol da partida, comemora } \\
\text { junto ao jogador Everton a vantagem que acabavam de adquirir para o jogo de } \\
\text { volta na Argentina pela fase final do campeonato sul-americano. }\end{array}$ \\
\hline $\begin{array}{c}30 \text { de } \\
\text { novembro } \\
\text { de } 2017\end{array}$ & $\begin{array}{c}\text { Final } \\
\text { Jogo de } \\
\text { volta }\end{array}$ & $\begin{array}{l}\text { A capa possui em sua composição pelo menos quatro cores predominantes e a } \\
\text { tipografia tem o seu maior destaque no título da matéria que retrata o mais novo } \\
\text { campeão da américa, Grêmio Foot-Ball Porto Alegrense. A chamada "Tri da } \\
\text { américa" é alusiva ao tricampeonato conquistado pela equipe gaúcha e está } \\
\text { sobreposta a imagem onde os jogadores levantam a taça de campeão, momento } \\
\text { que simboliza o auge do jogador de futebol. A fotografia que abrange a capa } \\
\text { em quase sua totalidade ainda possui uma chuva de papéis picados na cor } \\
\text { amarelo/dourado. As linhas pretas que servem como divisórias de conteúdo no } \\
\text { jornal ZH desta vez possuem coloração azul, remetendo à cor que mais } \\
\text { identifica o clube gaúcho. }\end{array}$ \\
\hline
\end{tabular}




\section{Considerações finais}

No Brasil, o futebol é uma paixão nacional; o esporte é o mais conhecido por aqui e, em consequência disso, é um dos assuntos mais vendáveis nos meios de difusão de informações ${ }^{3}$. Seu mercado movimenta cifras exorbitantes por todo o globo, chegando aos bilhões, todos os anos. Enorme é, também, o número de torcedores e simpatizantes do esporte que acompanham, diariamente, as notícias sobre os seus clubes nas mais diversas mídias, sejam elas impressas ou digitais. Em 2017, um clube brasileiro, o Grêmio Foot-Ball Porto Alegrense, conquistou um dos títulos mais importantes do futebol sul-americano, a Copa Libertadores da América, e a sua trajetória até a conquista foi documentada pelos mais diversos meios, dentre eles o jornal.

Nesse sentido, o Zero Hora é o jornal mais lido do Rio Grande do Sul, e como qualquer jornal, possui sua capa como seu principal "gatilho de venda"; logo, a imagem detém uma função extremamente relevante para a definição da mensagem. Dessa forma, a problematização proposta para este trabalho questionava como, do ponto de vista imagético, apresentaram-se as capas do Jornal Zero Hora/RS no dia posterior aos jogos do Grêmio nas fases semifinal e final da Copa Libertadores da América 2017.

Em relação à hipótese, é possível afirmar que, após as análises, os resultados foram condizentes com o previsto pelos pesquisadores, confirmando a suposição inicialmente delineada, uma vez que as capas possuíam como foco os jogadores do time do Grêmio, em sua essência os personagens principais da partida; o tom mais azulado ganhou força por conta dos uniformes dos jogadores e até da torcida gremista; o sentimento do torcedor estava retratado nas imagens que eram de comemoração e alívio.

Foram constatadas algumas adversidades durante a realização deste estudo, como, por exemplo, a dificuldade em encontrar referências bibliográficas sobre a Copa Libertadores da América. Destaca-se, contudo, que esta circunstância não comprometeu os resultados expostos no trabalho. Como sugestão para novos estudos, pode-se aplicar um novo estudo de caso, analisando o mesmo contexto, porém, com os jornais gaúchos concorrentes à Zero Hora (Correio do Povo, Diário Gaúcho, O Sul, etc), examinando, assim, a forma como outros jornais abordaram as mesmas situações analisadas neste trabalho. Outra possibilidade é realizar o mesmo estudo com o jornal Zero Hora,

\footnotetext{
${ }^{3}$ Disponível em: <http://espn.com.br/blogs/gustavohofman/406670_quando-o-futebol-nao-e-apenas-umjogo>. Acesso em: 03 fev. 2019.
} 
entretanto, tendo como objeto de estudo o clube arquirrival do Grêmio, o Sport Club Internacional. Esta análise poderá ser utilizada para comparação e observação de diferenças na maneira como o veículo divulga os resultados dos dois principais clubes do Rio Grande do Sul.

\section{Referências}

AMBROSE, Gavin; HARRIS, Paul. Cor. Porto Alegre, RS: Bookman, 2009. 176 p. Imagem. São Paulo, SP: Bookman, 2005. 175 p.

CESAR, Newton. Direção de arte em propaganda. 10. ed. Brasília, DF: Senac-DF, 2013.

DELEUZE, Gilles. Dúvidas sobre o imaginário in Conversações. Rio de Janeiro: Ed. 34, 1992.

DONDIS, D. A. Sintaxe da comunicação visual. Tradução Jefferson Luiz Camargo. São Paulo: Martins Fontes, 1997.

FONSECA, Joaquim da. Tipografia \& design gráfico: design e produção gráfica de impressos e livros. Porto Alegre, RS: Bookman, 2008. 280 p.

FRASER, Tom; BANKS, Adam. O essencial da cor no design. São Paulo, SP: SENAC, 2013. $256 \mathrm{p}$.

HEDGECOE, John. O novo manual de fotografia. 4. ed., rev. e atual. São Paulo, SP: SENAC São Paulo, 2005. 416 p.

JOLY, Martine. Introdução à análise da imagem. Campinas, SP: Papirus, 1996. 152 p. LANGFORD, Michael John. Fotografia básica. 5. ed., rev. aument. Lisboa: Dinalivro, 2003. 354 p.

NIEMEYER, Lucy. Tipografia: Uma apresentação. 4 ed. Teresópolis - RJ: 2AB, 2010. 105 p.SAMPAIO, Rafael. Propaganda de a a z. 3 ed. Rio de Janeiro: Campus, 2003. $390 \mathrm{p}$.

PEDROSA, Israel. Da cor a cor inexistente. [10. ed.]. Rio de Janeiro, RJ: SENAC, c2009. 254 p.

PRÄKEL, David. Composição. Porto Alegre, RS: Bookman, 2013. 175 p.

SANTAELLA, Lúcia; NÖTH, Winfried. Imagem: cognição, semiótica, mídia. São Paulo, SP: Iluminuras, 1997. 232 p.

SHOR, E. Political Leaning and Coverage Sentiment: Are Conservative Newspapers More Negative Toward Women? Social Science Quarterly, v. 100, Issue 1, Februaryy 2019, p. 307-319.

STRUNCK, Gilberto Luiz Teixeira Leite. Como criar identidades visuais para marcas de sucesso. 4. ed. Rio de Janeiro, RJ: Rio Books, 2012. 199 p.

TEKELI-YESIL, S.; KAYA, M.; TANNER, M. The role of the print media in earthquake risk communication: Information available between 1996 and 2014 in Turkish newspapers. International Journal of Disaster Risk Reduction, v. 33, February 2019, p. 284-289. 